\title{
The Intertrophic Relationship between Algae and Bacteria from the Activated Microalgae Granules
}

\begin{abstract}
COSTEL BUMBAC\#, ELENA MANEA\#, CATALINA STOICA, ALINA BANCIU, IOANA IONESCU, VALERIU BADESCU, MIHAI NITA-LAZAR*

National Research and Development Institute for Industrial Ecology - ECOIND, 71-73 Drumul Podu Dambovitei Str., 060652, Bucharest, Romania

Activated microalgae granules, as a technology at its initial steps, require sustained efforts for a better understanding of the intertrophic relationship between algae and bacteria. The activated algae granules samples from extensive lab-scale sequencing batch reactor experiments were selected for a total DNA extraction and analysis. A relative quantitative analysis of bacterial genes involved in nitrification, denitrification, phosphorus accumulation as well as genes belonging to microalgae was performed by realtime PCR / qPCR. Microscopic investigations of activated microalgae granule showed a gradual decrease of microalgae concentration, together with an increase in bacterial populations inside the granule.
\end{abstract}

Keywords: microalgae, bacteria, activated sludge

\begin{abstract}
Wastewater treatment importance is given by the need of increasing the quality of effluents prior their discharge into environment, in order to reduce the pollution impact on the receiving bodies [1]. In the past years, pollutants loads in wastewater have increased due to population increase and industrialization. Conventional wastewater treatment plants rely on physico-chemical and biological processes (most often activated sludge) [2, 3] for organics and nutrients removal. Due to the need for nutrients removal, the activated sludge systems operation and design has increased costs (for pumping and external aeration, aeration alone represent approximatively $50 \%$ of all pow er costs of a wastewater treatment plant), resulting in the need for identifying new cost-efficient solutions that can lead to effluents complying to the legislative requirements $[4,5]$. Moreover, at the present, the current by-products of activated sludge systems are mostly
\end{abstract} considered and treated as wastes.

Wastewater treatment costs must be signiûcantly reduced while maintaining an increased treatment efficiency and a reduced environmental impact [6]. Thus, a new algae-based technology emerged as a better option for wastewater treatment with a low cost and high efficiency, generating useful products instead of excess sludge. The main challenge for the use of microalgae in wastewater treatment is algae harvesting [7] due to their settling characteristics and operational conditions. The limitations identified so far for using symbiotic aggregates of microalgae and activated sludge have included biomass composition control difficulties, (that can be obtained by the selection of the desired species), identification of an algae and bacteria biomass optimal ratio, micro-pollutants removal efficiencies and the potential need for external $\mathrm{CO}$, source. Reports on algae-bacteria interactions [8- 11] and studies on the influence of basic operational parameters: hydraulic retention time, organic loading rate [12] or light intensity [13] showed the potential of using activated algae granules in wastewater treatment.

The Workshop on Microalgal Based Wastewater Treatment Facilities at the $13^{\text {th }}$ IWA Leading Edge Technology (LET) Conference on Water and Wastewater Technologies provided experts the opportunity to share their findings and set research priorities to resolve remaining challenges around microalgae's applicability. This year, from the 27th to the 31st of May 2018, LET documented recent developments and applications on Microalgal Based Wastewater Treatment Facilities (ww w.iwa-let.org).

Another important parameter of the wastewater treatment is nitrogen compounds removal by nitrificationdenitrification. Nitrification is the biological oxidation of ammonium to nitrate. Two groups of organisms contribute to ammonia oxidation to nitrite :ammonium-oxidizing bacteria $(A O B)$ and ammonia-oxidizing archaea (AOA). The nitrification capacity of ammonia-oxidative bacteria relies on an enzyme system consisting of ammonium monooxygenase and hydroxylamine oxidoreductase. The enzimes role is to catalyze ammonium oxidation to nitrite via hydroxylamine as a intermediary compound. Further oxidation is catalysed by nitrite oxidoreductase (representing the most appropriate functional marker specific for nitrite-oxidant bacteria).

This paper analysed the intertrophic relationships between microalgae and bacteria in terms of metabolic dependencies as an essential data for further development of a new energy efficient wastewater treatment technology.

\section{Experimental part \\ DNA extraction and amplification}

Briefly, the microalgae-bacterial biological samples were collected and the extraction of genetic material (total DNA) was performed using a DNA extraction kit (MoBio PowerSoil DNA isolation kit). The obtained genetic material was purified and quantified at $260 \mathrm{~nm}$ wavelength using L-VIS plate (CLARIOSTAR microplate reader). Quantitative analysis of presence and expresion of certain genes belonging to bacterial populations involved in nitrification, denitrification, phosphorus accumulation as well as genes belonging to microalgae was performed by real-time PCR / qPCR (table 1).

\section{Microscopy}

The granules structure and morphology were observed by advanced techniques of confocal laser scanning microscopywith automatic XYZ scanning. 


\begin{tabular}{|c|c|c|}
\hline & Target & Nucleotide sequence $\left(5^{\prime}-3^{\prime}\right)$ \\
\hline & Primer & \\
\hline 1. & \multicolumn{2}{|l|}{ 16s rRNA Nitrospira } \\
\hline & $\begin{array}{l}n s r 1113 \mathrm{f} \\
n s r 1264 \mathrm{r}\end{array}$ & $\begin{array}{l}\text { CCTGCTTTCAGTTGCTACCG } \\
\text { GTTTGCAGCGCTTTGTACGC }\end{array}$ \\
\hline 2. & $\begin{array}{l}\text { Nitrosomonas } \\
\text { amo } 598 \mathrm{f} \\
\text { amo } 718 \mathrm{r}\end{array}$ & $\begin{array}{l}\text { GAATATGTTCGCCTGATTG } \\
\text { CAAAGTACCACCATACGCAG }\end{array}$ \\
\hline 3. & \multicolumn{2}{|l|}{ Ammoniu monooxigenase (AMO) } \\
\hline & $\begin{array}{l}\text { Amo A } 1 \mathrm{~F} \\
\text { Amo A2R }\end{array}$ & $\begin{array}{l}\text { GGGGTTTCTACTGGTGGT } \\
\text { CCCCTCKGSAAAGCCTCCTCC }\end{array}$ \\
\hline 4. & \multicolumn{2}{|l|}{ 16sRNA AOB (amonium oxydation bacteria) } \\
\hline & $\begin{array}{l}\text { CTO189FA/Ba } \\
\text { CTO189FC } \\
\text { CT0654R }\end{array}$ & $\begin{array}{l}\text { GGAGRAAAGCAGGGGATCG } \\
\text { GGAGGAAAGTAGGGGATCG } \\
\text { CTAGCYTTGTAGTTTCAAACGC }\end{array}$ \\
\hline 5. & \multicolumn{2}{|l|}{ 16s rRNA Nitrobacter } \\
\hline & $\begin{array}{l}\text { fgps } 872 \\
\text { fgps } 1269\end{array}$ & $\begin{array}{l}\text { TTTTTTGAGATTTGCTAG } \\
\text { CTAAAACTCAAAGGAATTGA }\end{array}$ \\
\hline 6. & \multicolumn{2}{|l|}{ Nitrite oxydoreductase gene (nxrB) } \\
\hline & $\begin{array}{l}n \times r \mathrm{~B} 1 \mathrm{~F} \\
n \times r \mathrm{~B} 1 \mathrm{R}\end{array}$ & $\begin{array}{l}\text { ACGTGGAGACCAAGCCGGG } \\
\text { CCGTGCTGTTGAYCTCGTTGA }\end{array}$ \\
\hline 7. & \multicolumn{2}{|l|}{ Nitrite reductase (nirK) } \\
\hline & $\begin{array}{l}\text { nir } \mathrm{K} 1 F \\
\text { nir } \mathrm{K} 5 \mathrm{R}\end{array}$ & $\begin{array}{l}\text { GGMATGGTKCCSTGGCA } \\
\text { GCCTCGATCAGRTTRTGGTT }\end{array}$ \\
\hline 8. & \multicolumn{2}{|l|}{ Nitrite reductase (nirS) } \\
\hline & $\begin{array}{l}\text { nirs } \mathrm{CD} 3 \mathrm{AF} \\
\text { nirs } \mathrm{R} 3\end{array}$ & $\begin{array}{l}\text { GTSAACGTSAAGGARACSGG- } \\
\text { GASTTCGGRTGSGTCTTGA }\end{array}$ \\
\hline 9. & $\begin{array}{l}\text { NO reductase } \\
\text { cnorb- } 2 \mathrm{~F} \\
\text { cnorb- } 6 \mathrm{R}\end{array}$ & $\begin{array}{l}\text { GACAAGNNNTACTGGTGGT } \\
\text { GAANCCCCANACNCCNGC }\end{array}$ \\
\hline 10. & $\begin{array}{l}\mathrm{N}_{2} \mathrm{O} \text { reductaza } \\
\text { nosz } \mathrm{F} \\
\text { nosz } 1622 \mathrm{R}\end{array}$ & $\begin{array}{l}\text { CGYTGTTCMTCGACAGCCAG } \\
\text { CGSACCTTSTTGCCSTYGCG }\end{array}$ \\
\hline 11. & \multicolumn{2}{|l|}{ Phosphorus accumulatig bacteria (PAO) } \\
\hline & $\begin{array}{l}\text { pao462f } \\
\text { pao651r } \\
\text { pao846r }\end{array}$ & $\begin{array}{l}\text { GTTAATACCCTGWGTAGATGACGG } \\
\text { CCCTCTGCCAAACTCCAG } \\
\text { GTTAGCTACGGCACTAAAAGG }\end{array}$ \\
\hline 12. & \multicolumn{2}{|l|}{ Universal- bacteria } \\
\hline & $\begin{array}{l}341 \mathrm{~F}^{-} \\
515 \mathrm{R}\end{array}$ & $\begin{array}{l}\text { CCTACGGGAGGCAGCAG } \\
\text { AATCCGCGGCTGGCA }\end{array}$ \\
\hline 13 & \multicolumn{2}{|l|}{ bisphosphate carboxylase } \\
\hline & $\begin{array}{l}\text { rbcL-M379 F } \\
\text { rbcLFP R }\end{array}$ & $\begin{array}{l}\text { GGTTTCAAAGCTYTWCGTGC } \\
\text { GTAAATACCACGGCTACGRTCTT }\end{array}$ \\
\hline 14. & \multicolumn{2}{|l|}{ universal chlorophyte primers } \\
\hline & $\begin{array}{l}\text { UCP4F } \\
\text { UCP4 R }\end{array}$ & $\begin{array}{l}\text { ACGATCTAAAAAMGCATACAT } \\
\text { AATTGTWTCDTTDGCACCDGAAG }\end{array}$ \\
\hline 15. & \multicolumn{2}{|l|}{ Universal: (bacteria and cyanobacteria) ${ }^{6}$} \\
\hline & $\begin{array}{l}\text { CYA106F } \\
\text { CYA359F } \\
\text { CYA781Ra } \\
\text { CYA781Rb }\end{array}$ & $\begin{array}{l}\text { CGGACGGGTGAGTAACGCGTGA } \\
\text { GGGGAATYTTCCGCAATGGG } \\
\text { GACTACTGGGGTATCTAATCCCATT } \\
\text { GACTACTGGGGTATCTAATCCCTTT }\end{array}$ \\
\hline
\end{tabular}

Table 1

THE OLIGONUCLEOTIDE PRIMER SETS USED IN THE AMPLIFICATION REACTION

borward primers CYA $106 \mathrm{~F}$ and CYA $359 \mathrm{~F}$ were used in altemative reactions with reverse primers

CYA $781 \mathrm{Ra}$ and CYA $781 \mathrm{Rb}$ in echimolar ratio

\section{Results and discussions}

The microalgae-bacteria granules were collected at different time intervals from a lab-scale sequencing batch reactor where the treatment process was carried out in the absence of external aeration, the oxygen requiered by the aerobic bacteria had being supplied exclusively by the photosynthesis process carried out by photoautotrophic microalgae in the light phase.

The DNA extraction and quantification of the seven microalgae-bacteria granules samples showed no significant difference in extraction yield (table 2).

To assess the microbial diversity and evolution of microbial populations (microalgae-bacteria) over time and under different operational conditions, specific and
DNA CONCENTRATION IN THE CONSIDERED SAMPLES

\begin{tabular}{|l|c|c|}
\hline Samples & A260nm (ng/microL) & A260/280 \\
\hline $\mathrm{X} 1$ & 23.83 & 1.8 \\
\hline $\mathrm{X} 2$ & 12.16 & 1.6 \\
\hline $\mathrm{X} 3$ & 20.59 & 1.6 \\
\hline $\mathrm{X} 4$ & 19.43 & 1.75 \\
\hline $\mathrm{X5}$ & 22.29 & 1.8 \\
\hline $\mathrm{X} 6$ & 21.92 & 1.8 \\
\hline $\mathrm{X} 7$ & 21.28 & 1.7 \\
\hline
\end{tabular}

quantitative analysis by real time PCR were performed. 100ng of DNA was amplified in the presence of the abovementioned primer sets following the protocol: a) denaturation of the initial DNA template $\left(10 \mathrm{~min}, 95^{\circ} \mathrm{C}\right)$; b) 
40 amplification cycles of denaturation at $95^{\circ} \mathrm{C}$ time 15 seconds, followed by 60 seconds specific binding of the primer template AND template and an amplification at $68^{\circ}$ C). Seven samples were chosen specifically based on the nitrification / denitrification (figs. 1,2 and 3) and phosphorus (fig. 4) removal performances and following significant variations of the operational parameters to evaluate the effect on the microbial populations in the activated microalgae granules.
Denitrification is the biological process by which nitrate is reduced gradually to nitric oxide (NO), nitrogen oxide and, finally, gaseous nitrogen using a complex enzymatic system coded by specific genes (Nirk or NirS, NorB and NosZ). Reduction of nitrite, catalyzed by nitrite reductase (Nir) is the key step in the denitrification process. Two different structurally similar but functionally equivalent nitrite reductases, which are translated from the nirS and nirk genes, are considered to be the predominantenzymes for catalysing nitrite reduction. Overall, the results showed no major difference between $\mathrm{NH}_{4}{ }^{+}{ }^{-} \mathrm{NO}_{2}{ }^{-}$nitrifying
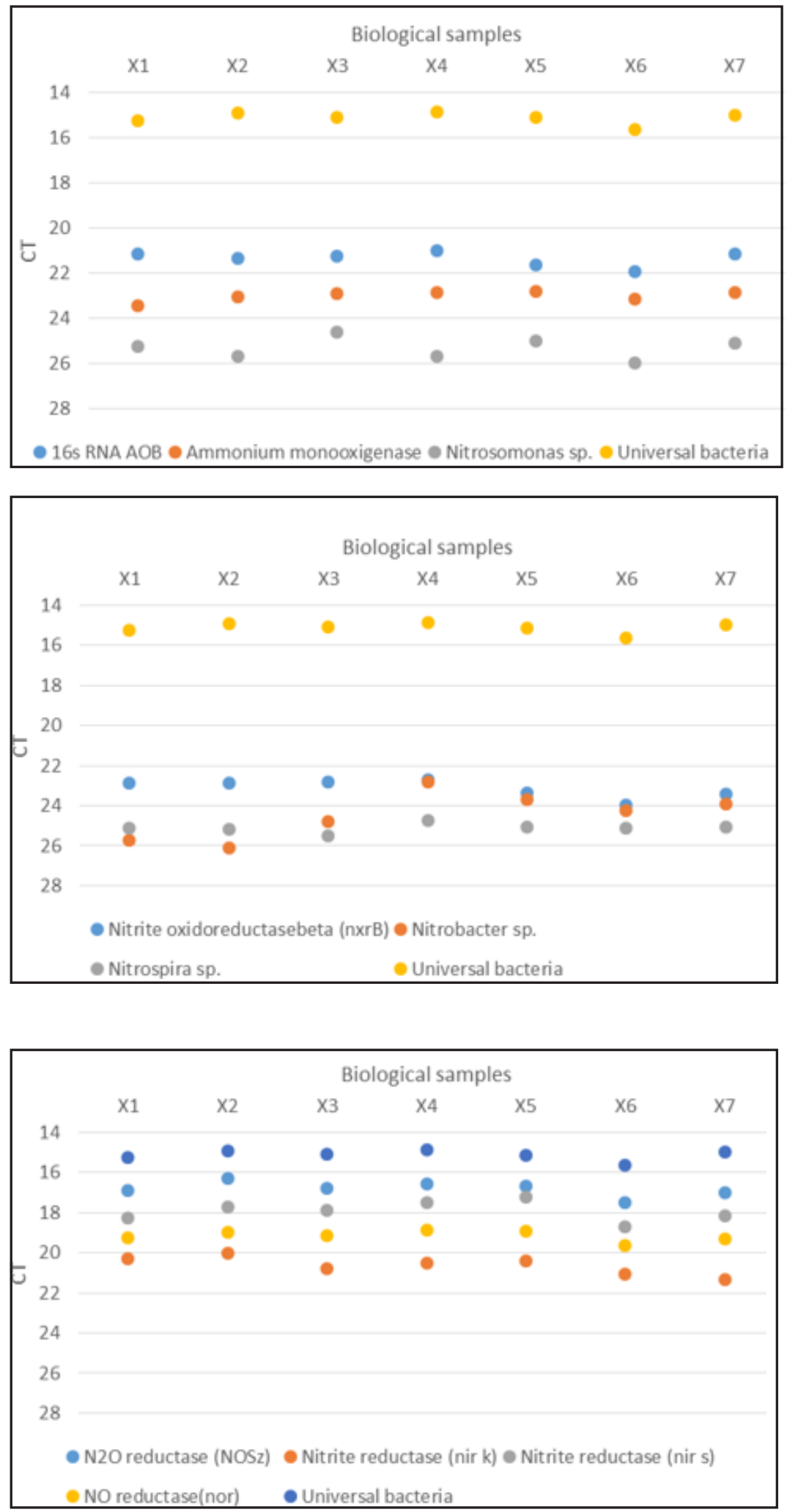

Fig. 1. Diversity and dynamics of nitrifying microorganisms (NH4-NO2)

Fig. 2. Diversity and dynamics of nitrifying microorganisms $\left(\mathrm{NO}_{2}-\mathrm{NO}_{3}\right)$
Fig. 3. Dynamics of genes involved in the synthesis of nitrogen oxides reductases corresponding to denitrifying heterotrophic microorganisms 

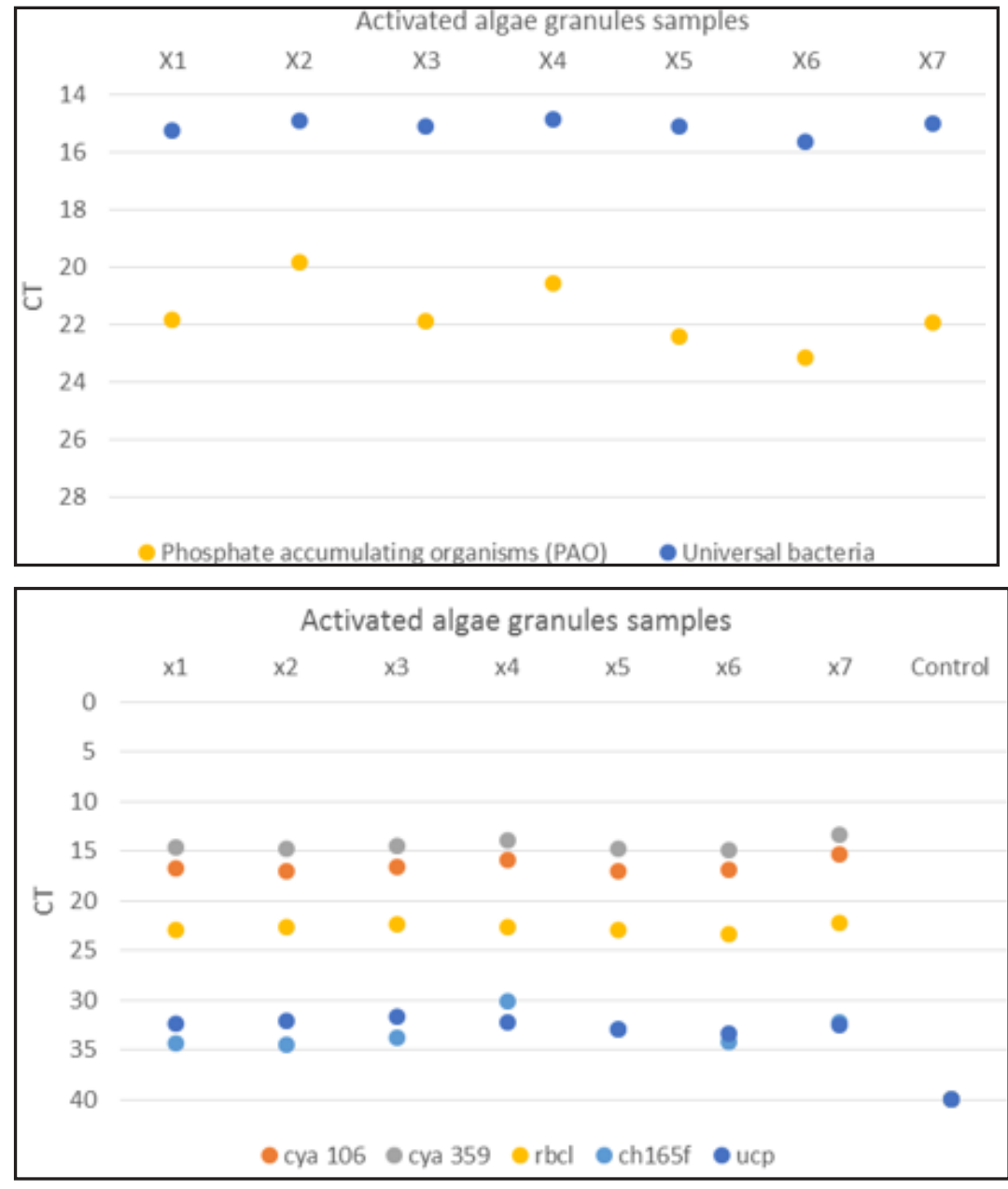

Fig. 5. Diversity and dynamics of photosynthetic microorganisms and the share of total microorganisms

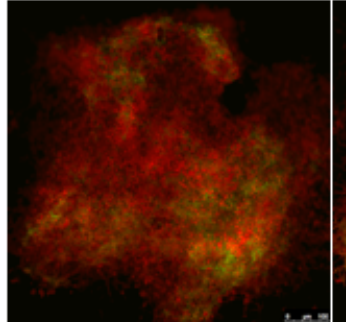

A

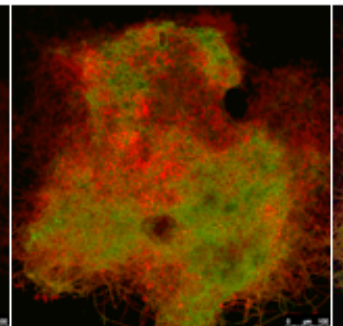

B

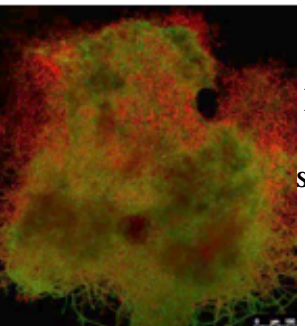

C

microorganisms (fig. 1), a certain balance between species/genes being observed for all samples. Within the granules, among the $\mathrm{NO}^{-}=\mathrm{NO}_{3}$ - nitrifying microorganisms Nitrobacter sp. encountered favorable conditions for development and enrichment (fig. 2) in the biological samples collected after a longer period of maturation (biological samples X4 to X7). The abundances of gene copy numbers $\mathrm{N}_{2} \mathrm{O}$ and nitrite reductase showed reduced variations over time (fig. 3) and correlates with the universal bacteria showing that a large portion of the bacteria in the granules are heterotrophic denitrifies.

The results have shown an important share of phosphorus accumulation microorganisms (fig. 4), PAOs representing about $25 \%$ of the total microorganisms (Universal bacteria) in the activated microalgae granules. Also, the diversity and dynamics of photosynthetic microorganisms from total microorganisms (fig. 5) results showed that chlorophyll (ch165 / ucp) microorganisms have the smallest share in activated algae granules, followed by photosynthesis ( $\mathrm{rbcl}$ ) compared to total cya present in microalgae-bacteria granules.

Microscopic investigations of activated microalgae granule (fig. 6) showed a gradual decrease of microalgae concentration, together with an increase in bacterial populations inside the granule (focusing minus $0.3 \mu \mathrm{m}$ from (minus $17.4 \mu \mathrm{m}$ from the granule surface) .

The results correlated with the metabolic processes through which the microalgae use the sun's energy and synthesize the metabodies that are used by the bacteria embedded inside the granule. Also, the emission observed in figure 6 in the range of $500-540 \mathrm{~nm}$ is exclusively due to the dye and not to the chlorophyll.

\section{Conclusions}

The induced symbiosis between microalgae and bacteria led to an activated microalgae granular structure where bacteria was surrounded by microalgae. This structural configuration fits the hypothesis that microalgae use the $\mathrm{CO}_{2}$ from the bacterial biodegradation of organic matter while microalgae, through photosinthesis produces the $\mathrm{O}$, which is used at its turn by the bacteria in the biodegradation processes.

The activated microalgae granules have a dynamic structure which adapts to the influent composition and operational conditions. Overall, the use of the microalgaebacteria symbiotic relationship could be an option to replace the conventional activated sludge used in the wastewater treatment. 
Acknowledgements: This research was supported by grant PN-III-P4ID-PCE-2016-0865 from the Romanian National Authority for Scientific Research and Innovation CNCS/CCCDI-UEFISCDI. Authors thank to Sabrina Rosoiu for her inputs.

\section{References}

1.STOICA, C., VASILE, G.G., BANCIU, A., LUCACIU, I., NITA LAZAR, M., Rev. Chim. (Bucharest), 68, no. 8, 2016, p. 1744.

2.NITA-LAZAR, M., GALAON, T., BANCIU, A., PAUN, I., STOICA, C., LUCACIU, I., J. Environ. Prot. Ecol., 17, no. 1, 2016, p. 237.

3. NITA-LAZAR, M., GHEORGHE, S., ANGHELACHE, A., BANCIU, A., STOICA, C., LUCACIU, I., Rev. Chim. (Bucharest), 67, no. 8, 2016, p. 1454.

4. OLGUIN, E.J., Biotechnol. Adv., 30, no. 5, 2012, p. 1031.

5.EDDY METCALF, Treatment and Reuse, 4 edn, McGraw-Hill, New York, 2004.
6. GHEORGHE, S., VASILE, G.G., STOICA, C., NITA LAZAR M., LUCACIU, I., BANCIU, A. Rev. Chim. (Bucharest), 67, no. 8, 2016, p. 1469.

7.TIRON, O., BUMBAC, C., MANEA, E., STEFANESCU, M., NITA-LAZAR, M., Scientific Reports, 7, 4646, 2017, p.1.

8. RAMANAN, R., BYUNG-HYUK, K., DAE-HYUN, C., HEE-MOCK, O., HEE-SIK, K., Biotechnol. Adv., 34, 2016, p 14.

9. ARCILA, J. S., BUITRON, G., J. Chem. Technol. Biotechnol. 91, no 11, 2016, p 2862.

10. TIRON, O., BUMBAC, C., PATROESCU, V., STEFANESCU, M., J. Biotechnol., 208, S19, 2015a.

11.TIRON, O., BUMBAC, C., PATROESCU, I. V., BADESCU, V. R., POSTOLACHE, C., Water Sci. Technol., 71.6, 2015b, p 832.

12. LIU, S., ZHANG, G., ZHANG, J., LI, X., LI, J., Bioresour. Technol., 200, 2016, p 245.

13. VERGARA, C., MUNOZ, R., CAMPOS, J.L., SEEGER, M., JEISONA, D., Int. Biodeterior. Biodegradation, 114, 2016, p 116.

Manuscript received: 12.08 .2018 